\title{
EFEK KONVERGENSI KERANGKA DASAR IFRS (IAS 12 REVISI) TERHADAP PSAK 46
}

\author{
Ida Kristiana \\ Prodi Akuntansi Universitas Muhammadiyah Semarang \\ ida.kristiana@unimus.ac.id
}

Riwayat Artikel: Dikirim Agustus 2017; Diterima September 2017; Diterbitkan September 2017

\begin{abstract}
This purpose of this study to examine the presence or absence of securities caused by the convergence of IFRS to Statement of Accounting Standards of Income Tax (PSAK 46), by simulating the financial statements of PT. Garuda Indonesia Airlines (GIA) and PT. Telkom Indonesia. This study also looks at the differences between financial reports that are not convergent compared with financial reports that are already convergent with IFRS

This study used a comparison method between the statements presented in IFRS with the statements presented in PSAK 46. The unit of analysis in this study is the International Financial Reporting Standard (IFRS) and Statement of Financial Accounting Standards on income tax accounting as well as books and articles related toboth.

The results of this study indicate that the convergence of the IFRS framework to PSAK 46 has a significant impact on the financial statements, especially on capital budgeting, because the tax will affect the calculation of cash flow. Besides this convergence also has an impact on the tax calculation in the financial statements
\end{abstract}

Keywords: IFRS, PSAK, Financial Statement, Convergence 


\section{PENDAHULUAN}

Konvergensi standar akuntansi pada dasarnya adalah penyamaan bahasa bisnis. Setiap negara mempunyai lembaga pengatur standar pelaporan keuangan. Indonesia mempunyai Ikatan Akuntan Indonesia yang mengeluarkan Pernyataan Standar Akuntansi Keuangan sebagai standar yang diterima sebagai bahas bisnis perusahaan-perusahaan di Indonesia. Amerika Serikat mempunyai Generally Accepted Acounting Principles (GAAP) yang didirikan oleh Financial Accounting Standard Board (FASB). Uni Eropa mempunyai International Accounting Standard Board (IASB).

Proses menuju IFRS di Indonesia dilakukan dengan cara melakukan penyesuaian dan harmonisasi terhadap IAS yang telah ada. Seiring dengan perkembangan bisnis dan pasar keuangan yang telah banyak menuju internasionalisasi, maka harmonisasi dalam pernyataan standar akuntansi internasional (IAS) dengan pernyataan standar akuntansi keuangan nasional (SAK) menjadi sangat penting.

Terbitnya IAS 12 revisi tentang acconting for income tax yang menggantikan IAS 12 asli melarang adanya penggunaan metode tangguhan atau kewajiban yang dikenal sebagai metode pasif berdasarkan pendapatan, sehingga membutuhkan penerapan lain dari metode pasif, yaitu metode pasif berdasarkan neraca dimana salah satu konsekuensinya adalah mendiscounted penerapan nilai wajar (http://www.WorldGAAPInfo.com).

Penilaian dan interprestasi dari para pelaku akuntansi memungkinkan untuk melaksanakan strategi yang tepat dalam penerapan standar akuntansi tentang pajak penghasilan, apakah penerapan unsur-unsur dan prinsip-prinsip akuntansi pajak penghasilan dipengaruhi oleh lingkungan dan budaya yang ada di Indonesia. Doupnik dan Salter (1995) menggambarkan bahwa budaya memiliki

pengaruh yang luas pada praktek akuntansi melalui norma-norma dan nilai-nilai, sehingga kelompok budaya yang berbeda dalam akuntansi akan menghasilkan interpretasi, penilaian dan konsep akuntansi yang berbeda.

Teori Akuntansi telah meniadi dasar

dalam penelitian ini, dimana akuntansi yang dipraktikkan dalam suatu wilayah negara merupakan suatu hasil rancangan dan pengembangan untuk mencapai suatu tujuan sosial tertentu, praktik akuntansi tersebut tentu dipengaruhi oleh berbagai faktor lingkungan seperti faktor sosial, ekonomi, politik dan sebagainya.Pelatihan akuntansi menjadi aktivitas manusia yang dipengaruhi oleh interpretasi dan penilaian dalam menerapkan konsep-konsep dan prinsip-prinsip akuntansi, unsur akuntansi dipengaruhi oleh lingkungan terutama faktor budaya.

Lingkungan akuntansi berpengaruh langsung terhadap tujuan akuntansi dan penjabaran prinsip serta aturan secara logis. Tidak semua aspek masyarakat relevan bagi akuntansi, beberapa tidak relevan, beberapa lainnya relevan secara tidak langsung. Aspek masyarakat yang relevan secara langsung adalah aspek ekonomi, sosial dan politik (Belkoui,1998). Unit kesatuan ekonomi akan beroperasi selama periode waktu yang tak terbatas untuk melaksanakan komitmen yang ada, dan tidak bermaksud untuk melikuidasi atau mengurangi secara material skala usahanya. Jika likuidasi terpaksa dilakukan maka prosedur akuntansi yang biasa tidak dapat diterapkan lagi, harus disusun dengan dasar yang berbeda dan dasar yang digunakan harus diungkapkan.

7. Hal ini tidak terlepas dari masalah pembayaran $\mathrm{PPh}$ dimana pengakuan, pengungkapan, dan alokasi telah diatur dalam PSAK 46. Namun seiring dengan perkembangan standar internasional, maka Indonesia harus mengambil keputusan apakah akan mengadopsi atau tidak mengadopsi IAS 12 yaitu Accounting For Income Tax yang merupakan salah satu isi dari IFRS. Adanya konvergensi IFRS terhadap pernyataan standar akuntansi keuangan tentang akuntansi pajak penghasilan tidak menutup kemungkinan akan memberikan pemahaman yang berbeda pada lingkungan bisnis di Indonesia.

\section{PERUMUSAN MASALAH}

Untuk mengadopsi standar internasional bukanlah perkara yang mudah karena memerlukan pemahaman dan menimbulkan dampak serta konsekuensi bagi negara yang mengadopsinya, sehingga permasalahan yang dirumuskan dalam penelitian ini adalah:

1. Bagaimana efek konvergensi kerangka dasar IFRS terhadap Pernyataan Standar Akuntansi Keuangan tentang Akuntansi Pajak Penghasilan.

2. Bagaimana efek konvergensi kerangka dasar IFRS terhadap IAS 12 (revisi).

3. Bagaimana efek koncergensi IAS 12

mengacu pada kerangka dasar IFRS terhadap pernyataan standar akuntansi keuangan tentang akuntasi pajak penghasilan. 


\section{METODE PENELITIAN}

Penelitian ini merupakan merupakan penelitian fundamental yaitu penelitian yang berorientasi pada penjelasan atau mengantisipasi suatu gejala, kaidah, model atau postulat baru yang mendukung suatu proses, teknologi lain dan tidak diukur keberhasilannya berupa produk dalam waktu singkat, tetapi berupa modal ilmiah yang mendasari penelitian terapan (Dikti,2006), menggunakan pendekatan diskriptif dengan analisis isi (content analysis) yang dilakukan dengan cara membandingkan kerangka dasar yang diatur dalam IFRS (IAS 12) dan PSAK 46 dan kemudian menganalisa hambatan yang timbul dengan adanya penerapan IFRS dan mengidentifikasi bagaimana hambatan tersebut dapat diselesaikan.

\section{Unit Analisis}

Unit analisis dalam penelitian ini adalah buku-buku dan artikel-artikel yang berhubungan dengan IFRS khusunya IAS 12 dan Pernyataan Standar Akuntansi Keuangan (PSAK 46.

\section{Diskripsi Objek Penelitian}

Penelitian ini diarahkan pada oyek penelitian PSAK 46 tentang akuntansi pajak penghasilan dan IAS 12 untuk mendapatkan jawaban atas identifikasi masalah yang dijabarkan dalam dua dimensi.

Dimensi pertama, adalah pengetahuan tentang Pernyataan Standar Akuntansi Keuangan 46, tentang efek yang terjadi dengan adanya konvergensi konsep dasar IFRS (IAS 12) terhadap pernyataan standar akuntansi keuangan tentang pajak penghasilan (PSAK 46). Dimensi kedua adalah pengetahuan tentang IFRS yaitu IAS 12, untuk mengetahui apakah konsekuensi yang harus ditanggung dengan melakukan konvergensi ke IFRS.

\section{Metode Pengumpulan Data}

Metode pengumpulan data yang digunakan dalam penelitian ini adalah metode dokumentasi yaitu sumber yang berasal dari International Financial Reporting Standard, IAS
12, PSAK 46 tentang akuntansi pajak penghasilan dan dokumen-dokumen pendukung lain.

\section{Teknik Analisis Data}

Teknik analisis yang digunakan dalam penelitian ini adalah analisis perbandingan dan menarik kesimpulan berdasarkan standar peraturan yang dierapkan dalam IAS 12 dan PSAK 46 dengan mengacu pada teori akuntansi yang berperan sebagai sains yang berfungsi untuk menjelaskan dan memprediksi. Menjelaskan berarti menganalisis dan memberi alasan mengapa fenomena dan fakta seperti yang diamati. Memprediksi berarti memberi keyakinan bahwa kalau asumsi-asumsi atau syarat-syarat yang diteorikan dipenuhi besar kemungkinan suatu fenomena atau fakta yang berisi semua analisis dan komponen-komponen yang menjadi sumber acuan untuk menjelaskan dan memprediksi gejalagejala atau peristiwa dalam akuntansi.

\section{HASIL DAN PEMBAHASAN}

Data dalam penelitian ini merupakan data sekunder yang berupa pernyataan standar akuntansi keuangan internasional IFRS yaitu IAS 12 dan PSAk 46, laporan keuangan PT. Garuda Indonesia Airlines (GIA), laporan keuangan PT. Telkom Indonesia, serta bukti-bukti pendukung lainnya.

\section{Perbandingan Antara IFRS dan PSAk46}

Perbandingan ini mengacu pada komponen dasar yang ada dalan kedua standar yaitu prinsip pengakuan, penilaian, dan pelaporan. Dari hasil perbandingan keduanya, terdapat beberapa persamaan pada beberapa komponen dasar yang berarti kedua standar telah melakukan penerapan yang sama sehingga PSAK tidak perlu melalukan adopsi terhadap IFRS yaitu IAS 12 . Selain itu dari perbandingan tersebut juga terdapat beberapa perbedaan yang berarti PSAK 46 harus melakukan adopsi terhadap standar yang diterapkan dalam IFRS yaitu IAS 12 yang disesuaikan dengan kondisi dan culture yang ada di Indonesia. Berikut penyajian dalam tabel.

Tabel

Perbandingan Standar menurut PSAK 46 dan IFRS (IAS 12)

\begin{tabular}{|c|c|c|c|}
\hline $\begin{array}{c}\text { Kompo-nen } \\
\text { Konsep } \\
\text { Dasar }\end{array}$ & \multicolumn{2}{|c|}{ Prinsip Pengakuan, Penilaian dan Pelaporan } & Keterangan \\
& PSAK 46 & Kerangka Dasar IFRS (IAS 12) & \\
\cline { 2 - 3 } & & \\
\hline
\end{tabular}




\begin{tabular}{|c|c|c|c|}
\hline $\begin{array}{l}\text { Scope } \\
\text { (Ruang } \\
\text { Ling-kup) }\end{array}$ & $\begin{array}{l}\text { PSAK tidak memiliki panduan } \\
\text { spesifik untuk } \\
\text { tangguhan atas } \\
\text { pemerintah }\end{array}$ & $\begin{array}{l}\text { Standar diterapkan dalam akuntansi } \\
\text { untuk pajak penghasilan, termasuk } \\
\text { akun-tansi untuk perbedaan } \\
\text { sementara yang mungkin timbul dari } \\
\text { hibah pemerintah. }\end{array}$ & 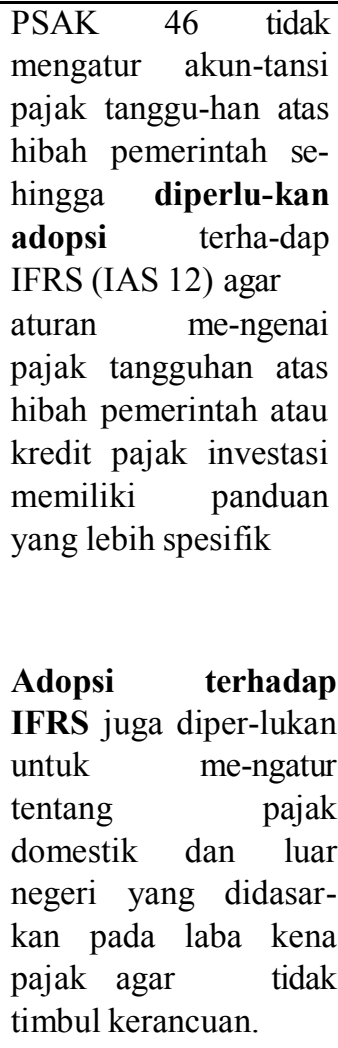 \\
\hline $\begin{array}{l}\text { Definisi } \\
\text { Aset Pajak } \\
\text { Tanggu-han }\end{array}$ & $\begin{array}{l}\text { Aset pajak tangguhan adalah } \\
\text { jumlah pajak penghasilan } \\
\text { terpulihkan (recoverable) pada } \\
\text { peri-ode mendatang akibat } \\
\text { dari: } \\
\text { a. Perbedaan temorer yang } \\
\text { boleh dikurang-kan dan } \\
\text { b. Sisa kompensasi ke- } \\
\text { rugian. } \\
\text { Tidak mengakui aset pajak } \\
\text { tangguhan dari akumulasi } \\
\text { kredit pajak yang belum } \\
\text { diman-faatkan. }\end{array}$ & $\begin{array}{l}\text { Aset pajak tangguhan diakui akibat } \\
\text { dari: } \\
\text { a. Perbedaan temporer dapat } \\
\text { dikurangkan } \\
\text { Akumalasi kredit pajak belum } \\
\text { diakumulasi } \\
\text { c. Akumulasi kredit pajak belum } \\
\text { dimanfaatkan jika peraturan } \\
\text { perpajakan mengijinkan }\end{array}$ & $\begin{array}{l}\text { Sama, } \\
\text { diperlukan } \begin{array}{r}\text { namun } \\
\text { adopsi }\end{array} \\
\text { terhadap IFRS (IAS } \\
\text { 12) agar ada peraturan } \\
\text { yang baku untuk } \\
\text { mengakui akumulasi } \\
\text { kredit pajakyang } \\
\text { belum dimanfaatkan } \\
\text { sebagai aset pajak } \\
\text { tanggu-han yang } \\
\text { disesuaikan de-ngan } \\
\text { kondisi yang ada di } \\
\text { Indonesia }\end{array}$ \\
\hline $\begin{array}{l}\text { Aktiva dan } \\
\text { Kewaji-ban } \\
\text { Pajak Kini }\end{array}$ & $\begin{array}{l}\text { Entitas harus } \\
\text { kewajiban pajak kini yang } \\
\text { belum dibayar sehubungan } \\
\text { dengan periode berjalan dan } \\
\text { periode-periode sebelumnya, } \\
\text { dan jika jumlah pajak yang } \\
\text { dibayar melebihi pajak yang } \\
\text { terutang pada periode tersebut } \\
\text { maka harus diakui sebagai } \\
\text { aktiva. }\end{array}$ & $\begin{array}{l}\text { Entitas harus mengakui kewajiban } \\
\text { pajak kini dalam neraca sehubungan } \\
\text { beban pajak kini dimasa sekarang dan } \\
\text { sebelum, sejauh sebelum dibayar. } \\
\text { Manfaat yang berkaitan dengan rugi } \\
\text { pajak yang ditarik kembali untuk } \\
\text { memulihkan pajak kini periode } \\
\text { sebelunya diakui sebagai aset. }\end{array}$ & $\begin{array}{l}\text { Sama, dalam hal } \\
\text { perlakuan akuntansi } \\
\text { terhadap aktiva dan } \\
\text { kewa-jiban pajak kini, } \\
\text { namun PSAK } \mathbf{4 6} \\
\text { tidak } 4 \text { mengatur } \\
\text { tentang pengakuan } \\
\text { asset yang timbul dari } \\
\text { manfaat yang } \\
\text { berkaitan dengan rugi } \\
\text { pajak yang ditarik } \\
\text { kembali rantuk } \\
\text { pemulihan pajak kini }\end{array}$ \\
\hline $\begin{array}{l}\text { Perbedaan } \\
\text { Temporer } \\
\text { kena Pajak }\end{array}$ & $\begin{array}{l}\text { Perbedaan temporer kena } \\
\text { pajak yang timbul dari } \\
\text { goodwill yang amorti-sasinya }\end{array}$ & $\begin{array}{l}\text { Kewajiban pajak untuk goodwill pada } \\
\text { pengakuan awal tidak diperhitungkan }\end{array}$ & $\begin{array}{l}\text { Perlu menga-dopsi } \\
\text { IAS } 12 \text { tidak hanya } \\
\text { mengecualikan }\end{array}$ \\
\hline
\end{tabular}




\begin{tabular}{|c|c|c|c|}
\hline $\begin{array}{l}\text { (Taxable } \\
\text { Tempora-ry } \\
\text { Diffe-rences }\end{array}$ & \begin{tabular}{l}
\multicolumn{3}{c|}{ tidak dapat dikurangkan untuk } \\
tujuan fiskal tidak \\
sebagai $\quad$ kewajiban \\
tangguhan
\end{tabular} & sebagai kewajiban pajak tangguhan & \begin{tabular}{lr}
\multicolumn{2}{l}{ perbedaan tem-porer } \\
yang berasal dari \\
goodwill & yang \\
amortisasinya & tidak \\
dapat digu-nakan & \\
untuk tujuan pajak \\
tetapi r \\
kewajiban pajak yang \\
timbul dari pengakuan \\
awal \\
dikecualikan dari \\
kewajiban goodwill \\
tangguhan.
\end{tabular} \\
\hline $\begin{array}{l}\text { Aktiva } \\
\text { Pajak } \\
\text { Tanggu-han }\end{array}$ & 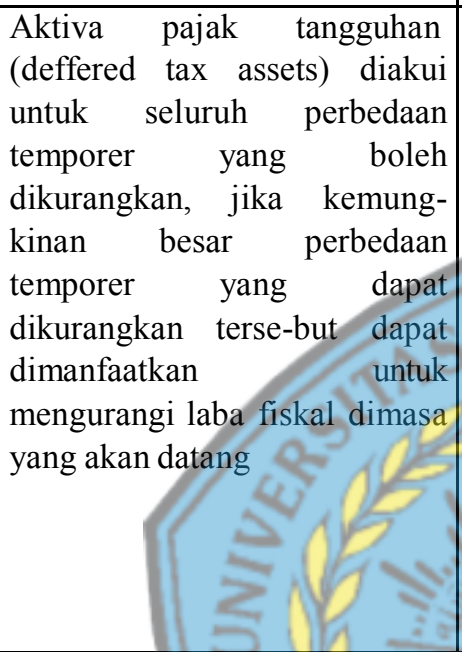 & $\begin{array}{l}\text { Aktiva pajak tangguhan dapat diakui } \\
\text { jika kemungkinan besar aktiva akan } \\
\text { direalisasi yang terdiri dari laba yang } \\
\text { dikenakan pajak dimasa mendatang. } \\
\text { Entitas dapat menciptakan aktiva } \\
\text { pajak tangguhan dari kerugian pajak } \\
\text { yang tidak digunakan }\end{array}$ & $\begin{array}{lr}\text { Sama, } & \text { namun } \\
\text { penciptaan } & \text { aktiva } \\
\text { pajak yang } & \text { tidak } \\
\text { digunakan oleh entitas } \\
\text { tidak dijelaskan }\end{array}$ \\
\hline $\begin{array}{l}\text { Pengaku-an } \\
\text { Pajak Kini } \\
\text { dan Pajak } \\
\text { yang } \\
\text { ditangguhka } \\
\text { n }\end{array}$ & 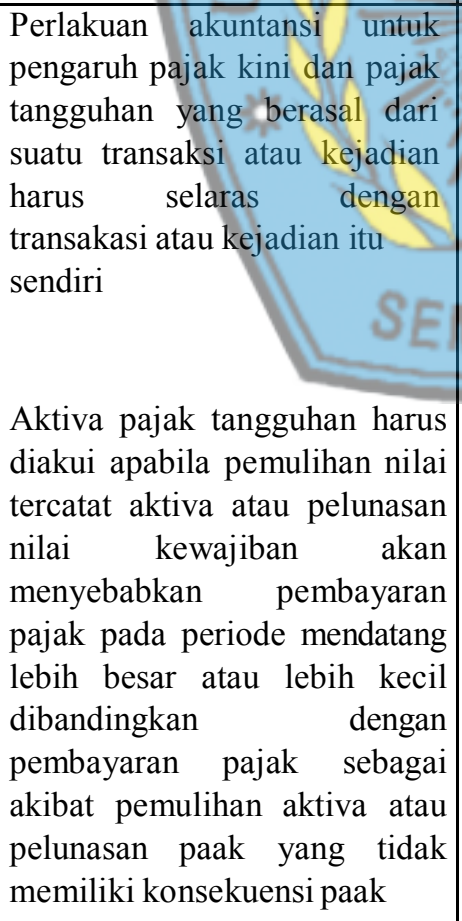 & $\begin{array}{l}\text { Pajak kini dan pajak yang } \\
\text { ditangguhkan diakui sebagai } \\
\text { pendapatan atau beban atau } \\
\text { dimasukkan kedalam keun-tungan } \\
\text { atau kerugian bersih periode } \\
\text { Pajak yang timbul dari penggabungan } \\
\text { bisnis diakui sebagai aktiva yang } \\
\text { dapat diidentifikasi atau kewajiban } \\
\text { pada saat likuidasi }\end{array}$ & $\begin{array}{l}\text { Perlu beberapa } \\
\text { penyesuaian dengan } \\
\text { IAS 12, yaitu tentang : } \\
\text { pengakuan pajak kini } \\
\text { dan pajak tangguhan } \\
\text { sebagai pendapatan } \\
\text { atau beban }\end{array}$ \\
\hline $\begin{array}{l}\text { Offset arus } \\
\text { aktiva dan } \\
\text { kewajiban } \\
\text { pajak }\end{array}$ & $\begin{array}{l}\text { Entitas harus diimbangi saat } \\
\text { aktiva pajak dan pajak kini } \\
\text { serta kewaji-ban menunjukkan } \\
\text { jumlah bersih pada neraca. }\end{array}$ & $\begin{array}{l}\text { Hanya diijinkan jika entitas: } \\
\text { a. memiliki kekuatan hukum hak } \\
\text { atau offset dan } \\
\text { b. bermaksud baik untuk } \\
\text { menyelesaikan dalam jumlah }\end{array}$ & 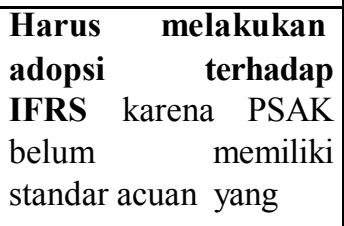 \\
\hline
\end{tabular}




\begin{tabular}{|c|c|c|c|}
\hline & & $\begin{array}{l}\text { bersih, atau untuk mereali- } \\
\text { sasikan asset dan menyele-saikan } \\
\text { kewajiban secara bersamaan }\end{array}$ & $\begin{array}{lr}\text { kuat } & \text { dalam } \\
\text { menentukan } & \text { offset } \\
\text { arus aktiva } & \text { dan } \\
\text { kewajiban pajak. } & \end{array}$ \\
\hline $\begin{array}{l}\text { Perbedaan } \\
\text { temporer } \\
\text { kena pajak } \\
\text { untuk aset } \\
\text { yang diukur } \\
\text { pada nilai } \\
\text { wajar }\end{array}$ & Tidak ada persyaratan khusus & $\begin{array}{l}\text { Perbedaan antara jumlah tercatat } \\
\text { revaluasi aset dan basis pajak } \\
\text { perusahaan adalah perbedaan } \\
\text { sementara dan menimbulkan suatu } \\
\text { kewajiban atau aset pajak tangguhan. }\end{array}$ & 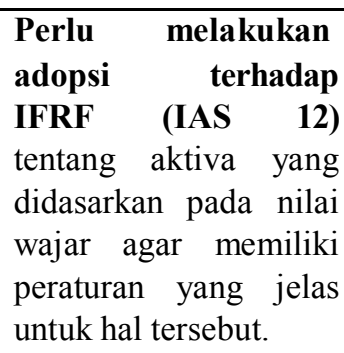 \\
\hline Goodwill & $\begin{array}{l}\text { Kewajiban pajak tanggu-han } \\
\text { (aset) tidak boleh diakui pada } \\
\text { goodwill (goodwill negatif) } \\
\text { yang diakui sesuai dengan } \\
\text { PSAK No } 22 \text { Penggabungan } \\
\text { usaha }\end{array}$ & $\begin{array}{l}\text { Syarat googwill dikurangkan untuk } \\
\text { tujuan pajak, kewajiban pajak } \\
\text { tangguhan untuk perbedaan temporer } \\
\text { kena pajak berhubungan dengan } \\
\text { goodwill }\end{array}$ & $\begin{array}{lr}\text { Perlu melakukan } \\
\text { adopsi IFRS (IAS 12) } \\
\text { tentang penga-kuan } \\
\text { perbedaan temporer } \\
\text { kena pajak sebagai } \\
\text { pajak tangguhan } \\
\text { kecuali jika perbe- } \\
\text { daan temporer kena } \\
\text { pajak itu timbul dari } \\
\text { penga-kuan awal } \\
\text { good-will atau pada } \\
\text { saat pengakuan awal } \\
\text { aset atau liabilitas dari } \\
\text { suatu entitas }\end{array}$ \\
\hline $\begin{array}{l}\text { Investasi } \\
\text { pada entiras } \\
\text { anak, } \\
\text { cabang dan } \\
\text { asosiasi dan } \\
\text { bagian } \\
\text { partisipasi } \\
\text { dalam } \\
\text { ventura } \\
\text { bersama }\end{array}$ & Tidak ada ketentuan & $\begin{array}{l}\text { Mengakui kewajiban pajak } \\
\text { tangguhan untuk semua perbedaan } \\
\text { temporer kena pajak dan perbedaan } \\
\text { temporer yang dapat dikurangkan, } \\
\text { kecuali jika perusahaan induk } \\
\text { investor atau cabang yang suka } \\
\text { mengambil risiko dapat mengontrol } \\
\text { waktu dari pembalikan perbedaan } \\
\text { sementara dan besar kemungkinan } \\
\text { bahwa perbedaan temorer tidak akan } \\
\text { mundur dalam masa depan. }\end{array}$ & $\begin{array}{l}\text { Perlu Mengadopsi } \\
\text { IFRS (IAS 12) }\end{array}$ \\
\hline $\begin{array}{l}\text { Deviden } \\
\text { (Kewaji-ban } \\
\text { pajak } \\
\text { berbasis } \\
\text { transaksi } \\
\text { pembaya- } \\
\text { ran saham) }\end{array}$ & Tidak ada ketentuan khusus & $\begin{array}{l}\text { Pajak tangguhan dihitung } \\
\text { berdasarkan pemotongan pajak untuk } \\
\text { pembayaran berbasis saham menurut } \\
\text { hukum pajak yang berlaku (yaitu } \\
\text { nilai intrinsik) }\end{array}$ & $\begin{array}{l}\text { Perlu mengadopsi } \\
\text { IFRS (IAS 12) untuk } \\
\text { mengatur deviden } \\
\text { (kewajiban pajak } \\
\text { berbasis transaksi } \\
\text { pembayaran saham) }\end{array}$ \\
\hline Disclou-sure & \begin{tabular}{lr|} 
Beberapa & \multicolumn{2}{c|}{ persyaratan } \\
pengungkapan & mirip dengan \\
IFRS &
\end{tabular} & $\begin{array}{l}\text { Pengungkapan lebih rinci diperlukan, } \\
\text { bebrapa dianta-ranya adalah agregat } \\
\text { sementara jumlah perbedaan terkait } \\
\text { dengan investasi di anak perusahaan, } \\
\text { cabang dan rekan serta bunga dalam } \\
\text { usaha patungan kewajiban pajak } \\
\text { tangguhan yang belum diakui. }\end{array}$ & $\begin{array}{l}\text { Sama, namun perlu } \\
\text { ada bebe-rapa } \\
\text { penyesuaian dengan } \\
\text { IAS } 12\end{array}$ \\
\hline
\end{tabular}




\begin{tabular}{|c|c|c|c|}
\hline $\begin{array}{l}\text { Penyajian } \\
\text { beban pajak }\end{array}$ & Tidak diatur & $\begin{array}{l}\text { Penyajian terpisah untuk beban } \\
\text { (penghasilan) pajak terkait laba rugi } \\
\text { dari aktivitas normal jika } \\
\text { menggunakan laporan laba rugi } \\
\text { terpisah. }\end{array}$ & $\begin{array}{lr}\text { Perlu melakukan } \\
\text { adopsi IFRS (IAS 12) }\end{array}$ \\
\hline Pengukuran & $\begin{array}{l}\text { Aset dan liabilitas pajak } \\
\text { tangguhan harus diukur } \\
\text { dengan menggunakan tarif } \\
\text { pajak yang akan berlaku pada } \\
\text { saat aktiva dipulihkan atau } \\
\text { kewa-jiban dilunasi, yaitu } \\
\text { dengan tarif pajak (peraturan } \\
\text { pajak) yang telah belaku atau } \\
\text { secara subtansi berlaku pada } \\
\text { tanggal neraca. }\end{array}$ & $\begin{array}{l}\text { Mengatur aset dan liabilitas pajak } \\
\text { tangguhan dengan tarif pajak dan } \\
\text { DPP konsisten dengan ekspektasi } \\
\text { dalam memulihkan dan menyelesai- } \\
\text { kan aset atau liabilitas. Dalam hal } \\
\text { perbedaan perlakuan pajak terhadap } \\
\text { pendistribusian laba, aset atau } \\
\text { liabilitas pajak kini dan tangguhan } \\
\text { diukur dengan tarif pajak terhadap laba } \\
\text { yang tidak terdistribusi }\end{array}$ & $\begin{array}{lr}\text { Perlu melakukan } \\
\text { adopsi IFRS (IAS 12) } \\
\text { untuk melaku-kan } \\
\text { beberapa } \\
\text { nyesuaian, karena ada } \\
\text { beberapa hal yg tidak } \\
\text { diatur dalam PSAK } 46\end{array}$ \\
\hline
\end{tabular}

Sumber : dikembangkan penulis untuk analisis

Efek konfergensi Kerangka Dasar IFRS Terhadap Pernyataan Standar Akuntansi Keuangan Tentang Pajak Penghasilan (PSAK 46)

Penelitian ini menggunakan laporan keuangan PT Garuda Indonesia Airlines dan PT Telkom Indonesia sebelum melakukan konvergensi dan sesudah melakukan konvergensi sebagai diskripsi atau gambaran. Sebelum melakukan konvergensi PSAK 46 menggunakan metode penangguhan (deffered method), yang mengacu pada prinsip kas yaitu jika kas diterima maka keuntungan diakui dan jika kas dibayar maka biaya diakui (APB 1967). Metode ini jug menggunakan pendekatan laba rugi (income statement approach) yang memandang perbedaan perlakuan antara akuntansi dan perpajakan dari sudut pandang laporan laba rugi, yaitu kapan suatu transaksi diakui dalam laporn laba rugi baik dari segi komersial maupun fiskal. Pendekatan ini mengenal istilah perbedaan waktu dan perbedaan permanen. Hasil dari pendekatan ini adalah pergerakan yang diakui sebagi pajak tangguhan pada laporan laba rugi.

Terbitnya IAS 12 (revisi) yang melarang penerapan metode tangguhan (differed method) yang menggunakan pendekatan laba rugi (income statement approach), mengharuskan untuk melakukan penerapa metode lain. Sesudah konvergensi standar nasional melakukan pembaharuan dengan menerapkan metode yang berbeda yaitu asset liability method (metode aset dan kewajiban) yang menggunakan pendekatan neraca (balance sheet approach) yang menekankan pada kegunaan laporan keuangan dalam mengevaluasi posisi keuangan dan memprediksikan aliran kas dimasa yang akan datang.

H. Konvergensi IFRS terhadap pernyataan standar akuntansi keuangan tentang pajak penghasilan berdampak terhadap pemakaian akun yang terdapat dalam laporan keuangan misalnyapenggunaan akun kewajiban pajak tangguhan berubah menjadi liabilitas pajak tangguhan.

Efek Konvergensi Kerangka Dasar IFRS Terhadap IAS 12 (Revisi)

PSAK 46 merupakan hasil adopsi dari pernyataan yang pernah dinyatakan FASB di Amerika Serikat yaitu SFAS N0. 109 tentang accounting for income tax dan SFAC dalam standar pernyataan internasional yaitu IAS 12 (revisi) tentang accounting for income tax. IAS No 12 (revisi) tersebut telah diadopsi oleh IASB (International Accounting Standard Boards) Sebagai IFRS (International Financial Reporting Standards) dalam makna luas sehingga tetap berlaku walaupun terjadi konvergensi standar akuntansi internasional menjadi IFRS (Pricewater house cooper,2005).

Efek Konvergensi IAS 12 Mengacu Pada Kerangka Dasar IFRS Terhadap Pernyataan Standar Akuntansi Keuangan Tentang Akuntansi Pajak Penghasilan (PSAK 46)

Dari hasil penelitian terhadap laporan keuangan PT. Garuda Indoenesia Airlines dan PT. Telkom Indonesia, konvergensi terhadap kerangka dasar IFRS memiliki dampak terhadap pernyataan standar akuntansi keuangan tentang pajak penghasilan, karena terdapat perbedaan 
pengaturan pajak menurut keduanya. Ketentuan yang berbeda itu adalah ketentuan tentang pajak final dan SKP (Surat Ketetapan Pajak) dan beban pajak.

\section{KESIMPULAN}

Kesimpulan pertama dari penelitian ini adalah bahwa efek konvergensi kerangka dasar IFRS terhadap pernyataan standar akuntansi keuangan tentang pajak penghasilan dengan mendiskripsikan laporan keuangan PT. Garuda Indonesia Airlines dan PT. Telkom Indonesia adalah memberikan dampak terhadap penerapan PSAK 46, misal penerapan metode asset liability dengan pendekatan neraca yang memberikan efek yang cukup berarti pada laporan keuangan PT. Garuda Indonesia dan PT. Telkom Indonesia yaitu meningkatkan daya banding informasi dari laporan keuangan masing-masing perusahaan.

\section{DAFTAR PUSTAKA}

\section{Simbolon, 2011. "Akuntansi Bisnis"}

Armstrong, C.S.,M.E Barth, et al., 2009. "Market Reaction to the Adoption of IFRS in Europe." The Accounting Review, Forthcoming.

Afifudin \& Beni Ahmad Saebani, 2009, Metodologi Penelitian Kualitatif.

Chariri, A., 2009. "Landasan Filsafat dan Metode Penelitian Kualitatif”, paper disajikan pada workshop metodologi penelitian kuantitatif dan kualitatif, laboratorium pengembangan akuntansi (LPA), Vakultas Ekonomi Universitas Diponegoro Semarang, $31 \mathrm{Juli}-1$ Agustus 2009.
Kesimpulan kedua, PSAK 46 tentang akuntansi pajak penghasilan merupakan hasil adopsi dari pernyataan yang dinyatakan oleh FASB di Amerika Serikat (yaitu SFAS No.109) tentang Accounting For Income Tax dan SFAC dalam standar pernyataan internasional (IAS No.12 revisi) tentang Accounting For Income Tax. IAS No. 12 (revisi) tersebut telah diadopsi oleh IASB (International Accounting Standard Boards) sebagai IFRS (International Financial Reporting Standards) dalam makna luas sehingga tetap berlaku walaupun terjadi konvergensi standar akuntansi internasional menjadi IFRS, karena pada dasarnya konsep dasar yang dinyatakan oleh FASB maupun IASB tidak jauh berbeda.

Kesimpulan ketiga tentang bagaimana efek konvergensi IAS 12 mengacu pada kerangka dasar IFRS terhadapa PSAK 46. Keputusan DSAK untuk melakukan konvergensi IFRS terhadap pernyataan standar akuntansi keuangan nasional tentang pajak penghasilan mempengaruhi penganggaran modal karena pajak akan berdampak pada perhitungan arus kas. Hal ini bisa kita lihat dari penerapan metode sebelum konvergensi yang menggunakan metode penangguhan yang memandang perbedaan perlakuan antara akuntansi perpajakan dari sudut pandang laporan laba rugi yang mengakui hasil hitungan dari pergerakan sebagai pajak tangguhan. Sedangkan laporan yang sudah melakuakn konvergensi lebih menggunakan metode aset dan kewajiban dengan pendekatan neraca yang menekankan kegunaan laporan keuangan dalam mengevaluasi posisi keuangan dan memprediksi aliran kas masa depan.
Cho et al.,1999 dalam Intan Immanuela, 2009. "Adopsi Penuh dan Harmonisasi Standar Akuntansi Internasional"

Daske, H., L. Hail, et al., 2009. “Adopting a Label : Heterogeneity in the Economic Consequences of IFRS Adoptions." Working paper.

Dwiermayanti.Wordpress.com,2009

Jeff $\mathrm{Ng}, 2009$. "Tax and Non Tax Incentives For Voluntary IFRS Adoption (artcle)

Daske,H., L. Hail, et al., 2008. "Mandatory IFRS Reporting Around the World : Early Evidence on the Economic Consequences." Journal of Accounting Research 46(5): 1085 - 1142

Natawidnyana, 2008. "International Financing Reporting Standards : A Brief Descreption." http://natawinyanawordpress.com/2008/10/28/InternationalFinancing-Reprting-Standards-ifrsabrief-description/. Diakses tanggal 18 Mei 2010

Forum of Firm 2007. "Perspective of the global application of IFRS, International Federation of Accountants, New York.

Christensen, H. B., E. Lee, et al., 2007. "Crosssectional variation in the economic consequences of international accounting harmonization: The case of mandatory IFRS adoption in the UK." The International Journal of Accounting 42:341-379. 
Christensen, H. B., E. Lee, et al., 2007. "Incentive or standards: What determines accounting quality changes around IFRS adoption?" Working paper.

Dikti Panduan Pengelolaan Program Hibah DP2M Edisi VII, 2006.

Pricewaterhouse, Coopers, 2005. "International Financial Reporting Standards

Doupink, T.S. \& Tsakumis, G.T. 2004, “A critical Review of test of gray's theory of cultural relevance and sugestions for foture research", Journal of acconting literature, vol 23,pp. 1-48. Retreved january 14,2008, from http://www.clanoffice.p1/A-criticalreveiw-of-test-of-gry-stheory-of-culturalrelevance-and sugestions-for-future research.

Doupnik,T.S. \& Richer,M.2003. “Interpretation of uncertainty ekspressions: A crossnational Y', Accounting, Organizations and Society, Vol.28,pp. 15-35.

Donald E. Kieso. (2002. "Akuntansi Intermidiate"

Belkaoui, Ahmed, 1998. "Accounting Theory", Penerjemah Marwata, dkk., Salemba Empat, Jakarta.

Belkaoui, Ahmed, 1998. “Accounting Theory” Penerjemah Marwata, dkk., Salemba Empat, Jakarta.

Godfrey et.al, 1997 dalam Anis dan Imam, 2003

IAI, 1997. "PSAK 46 tentang Akuntansi Pajak Penghasilan"

Baydoun, N. \& Willett,R., 1995, "Cultural Relevance of Western Accounting Systems in Developing Countries", ABACUS, vol.31,no.1,pp.67-92.

Doupnik,T.S.\& Salter, S.B., 1995. "External Environment, cuture, and acounting practice:A Preliminary test of general model of international accounting of development", The international journal of accounting, vol.28,pp 189-207.

Klaus Krippendorff, 1994. "Analisis isi pengantar dan metodologi, Rajawali perss, hlm.15

Belkoui, A.R.\& Picur,R.D., 1991. “ Cultural Determinism And The Perception of Accounting Concepts", The International Journal of Accounting, Vol.26,pp

Eldon s. Hendriksen, 1991. "Accounting Theory"
Flumoi, D.M., 1989. “ Analisa Isi Surat kabarSurat kabar Indonesia. Gajahmada University Press, Yokyakarta.

Gry, S.J.,1988. “Towards a theory of cultural influence on the development of accounting systems internationally, ABACUS, vol.24, no.1,pp.1-5

Watt R.\& Zimmerman, 1986. "Positive Accounting Theory"

Belkoui,A.R.,1980. "The interprofessional linguistic communication of accounting research, vol. 18,n0.2,pp.362-374

Kerlinger, F.N., 1973. "Fondation of Behavior Research".. Halt Renehart \& Winston Inc., New York

SFAS No. 109 Tentang Accounting For Income Tax

PSAK 46 "Pernyataan Standar Akuntansi Keuangan Tentangn akuntansi pajakPenghasilan" John Wiley Sons, IFRS practical implementation guide and wordbook scound edition (Guide and Wordbook)

http://puslit.petera.ac.id/journals/accounting http://www.managementfile.com/colomn.php?sub =finance\&id=149\&page $=$ finance

http://www.WorldgaapInfo.com 